against pathogenic Bacteria in heavily polluted water (Carlson et al., 1967).* But in any case the fact that the drinking-water, although chlorinated, is bacteriologically unsafe, constitutes a health hazard to the consumers in some areas of Jordan (Shehabi, in press).

It is well known that disinfection by chlorination is easy and effective in water having a low content of organic matter and favourable chemical analysis (Carlson, 1975). Therefore, it is absolutely necessary that further efforts be made to control water pollution and hence diseases from water sources in the future. Failure to achieve this will undoubtedly result in harmful effects on human health and the well-being of the community in Jordan.**

\section{SUMMARY}

The present bacteriological pollution of chlorinated drinking-water supplies in many regions of Jordan

* A referee points out, however, that these 'Results could easily be attributed to discontinuous chlorination.'-Ed.

** A referee comments: 'We agree that safe water-supply and hygienic waste-disposal are linked together-but it seems that the author has also made a good [case] for strengthened... 'surveillance of drinking-water quality and for additional or more effective facilities for water treatment.'-Ed. gives cause for considerable alarm, especially as it has been ascertained in the work described in this paper that faecal coliform Bacteria have already polluted $37 \%$ of the underground wells in the Amman-Zarqa area. Intensive efforts should be launched in order to prevent further pollution of ground-water in Jordan.

\section{References}

American Public Health Association (1971). Standard Methods for the Examination of Water and Waste Water, 13th edn. American Public Health Association, New York: $\mathrm{xxxv}+874 \mathrm{pp}$, illustr.

Carlson, Sven (1975). Current Problems of Water Hygiene. Unpublished manuscript, $10 \mathrm{pp}$.

Carlson, Sven, Hässelbarth, U. \& Mecke, P. (1967). Die Abhängigkeitder Keimtätenden Wirkung vom Redoxpotential. Zbl. Bakt. I Ref., 206, pp. 500-12.

Polunin, Nicholas (Ed.) (1972). The Environmental Future. Macmillan, London \& Basingstoke, and Barnes \& Noble, New York: xiv +660 pp., illustr.

Shehabi, AsEm (in press). A bacteriological study of an outbreak of waterborne infection. Jordan Medical Journal.

World Health Organization (1971). International Standards for Drinking-water, 3th edn. World Health Organization, Geneva, Switzerland: $70 \mathrm{pp}$.

World Health Organization (1974). Disposal of community wastewater. WHO Techn. Rep. Ser., No. 541, pp. 6-10.

\title{
Threats to Lake Atitlán, Guatemala
}

The Government of Guatemala has been urged by IUCN and WWF to reconsider proposals for hydroelectric and tourist projects involving Lake Atitlán, renowned as one of the world's most beautiful mountain lakes and the only known home of the flightless Atitlán or Giant Pied-billed Grebe (Podilymbus gigas, also known as 'Pato Zambullidor' and 'Poc'). In a letter addressed to President Kjell Garcia, these sister conservation organizations pointed out that the proposed hydroelectric project could have grave results through the drawdown of the Lake's waters and the diversion of mountain rivers into the Lake. The letter was accompanied by a memorandum setting out in detail the possible adverse ecological effects-including those of microbial and thermal pollution, turbidity, and eutrophication.

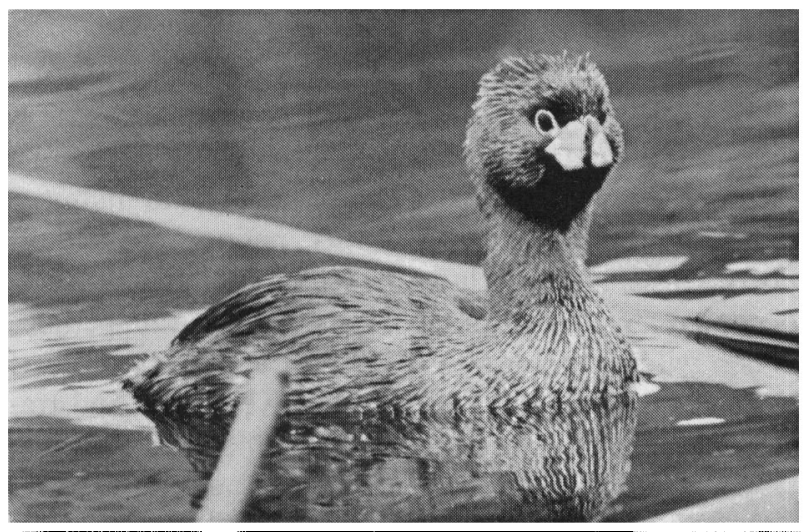

FIG. 1. Male Giant Pied-billed Grebe of Lake Atitlán, Guatemala. Feathers slightly raised in territorial display, and black throat slightly engorged. Photo: National Geographic Society.
The tourist projects which are causing concern involve construction of two 16-storey condominiums on the shores of the Lake. IUCN and WWF pointed out that these structures would detract from the general scenic beauty and, in addition, would almost certainly lead to impairment of water-quality through disposal of sewage, garbage, etc. They also stated that-as a matter of perhaps crucial importance-the life-styles of the local Amerindian people, who are carrying on the unique and distinctive Mayan culture, would be irretrievably disturbed.

The unique Atitlán Grebe (Fig. 1) was the subject of a WWF-funded conservation project some years ago, when it was threatened with extinction following the introduction of Largemouth Bass (Micropterus salmoides) for sport fishing. The Bass were reputed to eat not only Grebe chicks, but also native fishes, frogs, crabs, and ducklings.* Native fisheries were devastated, and the Grebes were reduced to only about 80 . Conservation measures included establishment of a special reserve, and appointment of a warden to protect the Grebes, which now number more than 200 .

\author{
Peter F. R. JAckson, Director of Information \\ World Wildlife Fund \\ 1110 Morges \\ Switzerland.
}

* According to the 1968 Project Report of the Director of 'Operation Protection Poc', Anne LaBastille (Bowes), 'Bass are the principle competitors for fish food with Grebes and Indians. Human inhabitants have undergone a decrease in protein intake due to the destruction of their fishing industry by these predacious fish. The critical mortality factor for Grebes, especially juveniles, appears to be starvation'.-Ed. 